\title{
Assessment of the Sustainability of Countries at Worldwide
}

\author{
Janaína M. de A. Dias ${ }^{1}$, Eduardo G. Salgado ${ }^{1}$, Sandro Barbosa ${ }^{1}$, Augusto D. Alvarenga ${ }^{1}$ \& Jean M. S. Lira ${ }^{1}$ \\ ${ }^{1}$ Exact Science Institute, Federal University of Alfenas, Alfenas, Minas Gerais State, Brazil \\ Correspondence: Eduardo G. Salgado, Exact Science Institute, Federal University of Alfenas, Alfenas, Minas \\ Gerais State, Brazil. E-mail: eduardosalgado@bcc.unifal-mg.edu.br
}

Received: August 25, 2017 Accepted: September 20, 2017 Online Published: October 25, 2017

doi:10.5539/jms.v7n4p51 URL: http://doi.org/10.5539/jms.v7n4p51

\begin{abstract}
For the quantification and ranking of sustainablility reliable indicators are needed in the economic, social and environmental areas. For this, decision-making methods have been used to identify and rank the most important indicators. However, it is important to know which method to use, since this choice can modify the result. Therefore, two methods of multi-criteria decision making were evaluated: Technique for Order Preference by Similarity to Ideal Solution (TOPSIS) and TOPSIS with Hierarchical Analytical Process (AHP). It was observed a difference between the methods tested, where the TOPSIS-AHP method presented better performance as a function of the weights assigned by the specialists. The research results demonstrated which countries have a more balanced sustainable development in environmental, social and economic levels together. In this case, the three most sustainable countries are Switzerland, Sweden and Norway. Additionally this research shows which countries are more sustainable taking into account each indicator separately. It is expected that the results provide a basis in decision-making and it contribute to the best choices in all aspects of sustainability.
\end{abstract}

Keywords: multi-criteria decision making, Sustainability indicators, TOPSIS, AHP

\section{Introduction}

Economic growth with the rational use of environmental resources and less social inequality is one of the premises of sustainable development. In this sense, countries seek to achieve this goal through the most diverse political, social, economic and environmental measures (Brundtland, 1985). Thus, assessing and quantifying sustainability in countries shows the overall situation of sustainable development. For this, sustainable development indicators (SDIs), which are important parameters used in the study of sustainability are used (Ciegs Ramanauskiene \& Startiene, 2015). SDIs can be obtained for different countries around the world, allowing comparisons and establishing ordering ranks for sustainability models (Wass et al., 2014). Human Development Index (HDI), Sustainable Economic Welfare Index (SEWI), Genuine Progress Index (GPI) and the Ecological Footprint (EF) are indicators that show the degree of development of a country or region (Weidmann et al., 2015). Each indicator has variables which assume different values in different countries (Rametsteiner, Pülzl, Alkan-Olsson \& Frederiksen, 2011; Shields, Solar \& Martin 2002). Therefore, it is necessary to select and hierarchize the variables to use them in the ranking of SDIs. Once the variables have been established it is possible to prioritize the indicators by the degree of importance, where in the evaluation and quantification of sustainability, the SDIs define the position that a country occupies in relation to the level of sustainability (Spangenberg, Pfahl \& Deller, 2002). SDI are used to collect, process and use information in order to make better decisions, drive more intelligent policy choices, measure progress and monitor feedback mechanisms in all pillars of sustainability. SDI is also used as an interaction between values and objectives, policy and science to increase the precision of the evaluation / quantification of various sustainability issues at different times (short, medium or long term) and spaces (international, national, regional, municipal or local) (Ramos \& Caeiro, 2010). In indicators economic, social and environmental have been chosen because of their importance for the establishment of sustainable development. Besides that, it is important to know what are the main variables for sustainability in the indicators and whether they differ between countries. As there are several SDIs, the definition and prioritization of indicators is an important step in the analysis and comparison of sustainability. Some approaches have been used to determine variables and indicators. Among these techniques, the use of decision-making models has been used (Egilmez Gumus \& Kucukvar, 2015).

Decision-making and ranking are widely used techniques for establishing priority SDIs (White \& Nobel 2013; Hossaini, Reza, Akhtar, Sadiq, \& Hewage, 2015). Two widespread decision-making methods are Technique for 
Order Preference by Similarity to Ideal Solution (TOPSIS) and Analytic Hierarchic Process (AHP), generally used separately to classify sustainability at the sectorial level (Ertugrul \& Karakaçoglu, 2009). However, these methods have been little used for SDIs analysis at the global level and interaction among SDIs. In addition, the use of TOPSIS-AHP together is still little explored in this type of analysis. Thus, this study aims to use different methods of multicriteria decision to define and prioritize variables into SDIs, also between the SDIs and through this, to achieve the ranking of the sustainability of the countries around the world. It measure sustainability performance through global metrics, compare rankings, using different decision-making methods, and verify differences and imbalances between degrees of sustainability among selected countries. In addition, the effectiveness of the TOPSIS-AHP model was tested for the ranking and prioritization of SDIs. In this context, three indicators were defined (economic, social and environmental) subdivided into 19 sustainability variables for 175 countries in the period 2013 and 2014 in order to assess and compare whether there is a sustainable development of these countries in the economic, social and environmental dimensions, when environmental conditions deteriorate every year.

The questions that guide the construction of this text were the following: Based on economic, social and environmental indicators, which countries are considered the most sustainable in the world? Is there a differentiation in the ranking between countries when analyzing the indicators separately? What are the main variables that impact differentiation for sustainability? Also, in order to corroborate with this general objective, the specific objectives are: To measure sustainability performance through global metrics, compare rankings, using different decision-making methods, and verify differences and imbalances between degrees of sustainability among selected countries.

This article is organized as follows. This first section presents the introduction to the research, its context, the research question, and objectives. The next section presents the research methodology. The following section presents the results that were obtained and discusses the findings. Finally, the last section presents the most important conclusions and contributions of this work, along with implications for future research and for practice.

\section{Materials and Methods}

For this research, the database of the World Bank and the United Nations Development Programme (UNDP) were was used as variables of indicators for implementing global sustainability assessments. The research was based on use of two methods of Multicriteria Support: TOPSIS and AHP. TOPSIS is a method which has been widely used with a variety of goals in various areas of knowledge (Behzadian, Otaghsara, Yazdani \& Ignatius, 2012). The basic principle of TOPSIS is to choose an alternative that is as close as possible to the positive ideal solution and as far as possible to the negative ideal solution. The ideal solution is formed by taking the best values achieved by the alternatives during the evaluation for each decision criterion, while the negative ideal solution is composed similarly, by taking the worst values. The application of TOPSIS method can be described as a series of successive steps which begin with the implementation of an original data matrix, which uses value criteria for each alternative, and then TOPSIS turns this original matrix into a matrix considered standardised (Bulgurcu, 2012).

This technique has three steps. The first one concerns the calculation of the positive ideal solutions $A^{*}$ and negative ideal solutions $A^{\prime}$, as follows Eqs. (1-2):

Positive ideal solution: $A^{*}=\left\{v 1^{*}, \ldots, v n^{*}\right\}$, where

$$
v j^{*}=\left\{\operatorname{maxi}(v i j) \text { if } j \in J \text {; mini (vij) if } j \in J^{\prime}\right\}
$$

Negative ideal solution: $A^{\prime}=\left\{\mathrm{v} 1 \ldots, v n^{\prime}\right\}$, where

$$
v^{\prime}=\left\{\operatorname{mini}(v i j) \text { if } j \in J \text {; maxi (vij) if } j \in J^{\prime}\right\}
$$

Where: $J$ and $J^{\prime}$ respectively represent the positive or negative variables.

The second step is the calculation of Euclidean distances, i.e., calculating the separation measure. This calculation of Euclidean distances between the benefits is then given by Eqs. (3-4):

The separation of the positive ideal alternative:

$$
S i *=\left[\Sigma j\left(v j^{*}-v i j\right) \exp 2\right] 1 / 2 i=1, \ldots, m
$$

Similarly, the separation of the negative ideal alternative:

$$
S^{\prime} i=\left[\Sigma j\left(v j^{\prime}-v i j\right) \exp 2\right] 1 / 2 i=1, \ldots, m
$$

With $i=1, \ldots, m$. The weights were used with values of $w i=1$. 
The third step of the TOPSIS method is the calculation of the relative proximity in relation to the ideal solution, as follows (Eq. 5):

$$
C i^{*}=S^{\prime} i /\left(S i^{*}+S^{\prime} i\right), 0<C i^{*}<1
$$

Finally, after the completion of these TOPSIS steps the ranking is drawn up so that the data closest to the ideal solution is designated as the first place in the rankings and so on. The other method used was the AHP created in 1971 which is considered to be a multi-criteria method that permits the analysis of qualitative variables in a decision process (Aragonés-Beltrán, Chaparro-González, Pastor-Ferrando, \& Pla-Rubio, 2014).

AHP develops a pair-wise comparison matrix on the basis of the criteria, and creates multiple square decision matrices, in which for each criteria and each alternative, a priority value is associated over the others under analysis, from a fundamental preference scale, the Saaty comparison scale (Table 1).

Table 1. Saaty comparison scale

\begin{tabular}{|c|c|c|}
\hline Intensity & Definition & Explanation \\
\hline 1 & Same importance & The two activities equally contribute to the goal \\
\hline 3 & Minor importance of one over the other & Experience and judgment slightly favour one activity over the other \\
\hline 5 & Great or essential importance & Experience or judgment strongly favour one activity over the other \\
\hline 7 & Extreme or demonstrated importance & $\begin{array}{l}\text { An activity is very strongly favoured over the other. It could be } \\
\text { demonstrated in practice }\end{array}$ \\
\hline 9 & Absolute importance & $\begin{array}{l}\text { The evidence favours one activity over the other, with the highest } \\
\text { degree of certainty }\end{array}$ \\
\hline $2,4,6,8$ & Intermediate values & When seeking a compromise condition between two settings \\
\hline $\begin{array}{l}\text { Reciprocals of the } \\
\text { above zero values }\end{array}$ & $\begin{array}{l}\text { If activity i receives one of the different } \\
\text { designations above zero, when } \\
\text { compared to activity } \mathrm{j} \text {, then } \mathrm{j} \text { has the } \\
\text { reciprocal value when compared with } \mathrm{i} \text {. }\end{array}$ & A reasonable designation \\
\hline Rational & Reasons arising from the scale & $\begin{array}{l}\text { If the consistency has to be forced to obtain numerical values } n \text {, to } \\
\text { complete the matrix }\end{array}$ \\
\hline
\end{tabular}

Source: SAATY, T. L. (1991)

In order to put into practice and analyze the judgments, it is necessary to form n-square matrices and their related eigenvectors. Equation 6 is used to demonstrate the relationship between the decision matrix and the eigenvector row, which is equivalent to the importance of one of the criteria, or of one of the alternatives classified into one of the criteria. $\lambda$ is the eigenvalues, and $\mathrm{A}$ is a square decision matrix of order $\mathrm{m}$.

$$
\mathrm{A} \omega=\lambda \omega
$$

Equation 7 is used to calculate the amount of judgments required for each array.

$$
Q=\sum_{i=1}^{* N=1} N t(N i-1) ; 2
$$

Each judgment matrix must have its weighted matrix calculated by dividing the elements of the column of the matrix by the sum of the same elements. Next step is to calculate the priority vector (standardized weights), which is possible through averaging the elements of each row. The standard weight indicates which of the criteria or alternatives is the most important. After that, Consistency Index (CI) is calculated with reference to the maximum eigenvalues $(\lambda \max )$ obtained and the number of elements analyzed (n). Maximum eigenvalues is calculated by multiplying the matrix of judgments by the vector of priorities; this result is then divided by the vector of priorities (Saaty, 2008).

One of the most crucial points in the AHP method is checking the consistency of judgments made by experts in the pair wise comparisons. For a judgment to be consistent it must present reason of consistency (RC) below $10 \%$, if the RC is higher than this it is necessary that the experts redo their analysis so that it can be used to create a priority scale. Equation 4 is used to calculate the $\mathrm{CR}$, which takes into account the IC and the random consistency index (RI) (Eq. 8). RI is determined by the number of elements as shown in Table 2.

Table 2. Random Consistency Index (RI)

\begin{tabular}{lllllllllll}
\hline $\mathrm{N}$ & $\mathbf{2}$ & $\mathbf{3}$ & $\mathbf{4}$ & $\mathbf{5}$ & $\mathbf{6}$ & $\mathbf{7}$ & $\mathbf{8}$ & $\mathbf{9}$ & $\mathbf{1 0}$ & $\mathbf{1 1}$ \\
\hline $\mathbf{R I}$ & 0 & 0,58 & 0,9 & 1,12 & 1,24 & 1,32 & 1,41 & 1,45 & 1,49 & 1,51 \\
\hline
\end{tabular}


Once completed the judgments, it is necessary to synthesize the priorities, and this can be achieved in two ways: Individual judgment aggregation (IJA) and individual priority aggregation (IPA) (Zu \& Xu 2014).

The SDIs and variables were chosen through the analysis of sustainable development carried out by the World Bank, PNUD and OECD whose data were obtained from European Union Statistics Office (Eurostat) and relevant (Luzzati \& Gucciardi, 2015; Bohringer \& Jochem, 2007; Distaso, 2007; Jingzhu \& Opschoor, 1999). Tables 3, 4 and 5 detail the variables selected for each indicator of sustainable development and the scale of the positive ideal solution (the higher the better $\mid$ and $\mathrm{j}$ the lower the better) used for the application of the TOPSIS method.

Table 3. Economic indicators

\begin{tabular}{|c|c|c|c|}
\hline \multicolumn{4}{|c|}{ Economic Indicators } \\
\hline Year & Variable & Details & $\begin{array}{l}\text { Positive Ideal } \\
\text { Solution Scale: }\end{array}$ \\
\hline 2014 & $\begin{array}{l}\text { Inflation, consumer } \\
\text { prices (annual\%) }\end{array}$ & $\begin{array}{l}\text { Inflation measured by the consumer price index reflects the annual } \\
\text { percentage change in the cost to the average consumer of acquiring } \\
\text { a basket of goods and services that may be fixed or changed at } \\
\text { specified intervals, such as yearly. }\end{array}$ & $\downarrow$ \\
\hline 2014 & GDP growth (annual\%) & $\begin{array}{l}\text { GDP annual percentage growth rate at market prices based on } \\
\text { constant local currency. GDP is the sum of gross value added by all } \\
\text { resident producers in the economy plus any taxes on products and } \\
\text { minus any subsidies not included in the value of the products. }\end{array}$ & $\uparrow$ \\
\hline 2014 & $\begin{array}{l}\text { GDP per capita (Current } \\
\text { US } \$ \text { ) }\end{array}$ & $\begin{array}{l}\text { GDP per capita is the gross domestic product divided by the } \\
\text { mid-year population. Data are in current US dollars. }\end{array}$ & $\uparrow$ \\
\hline 2013 & $\begin{array}{l}\text { High-tech exports } \\
\text { (Current US \$) }\end{array}$ & $\begin{array}{l}\text { High-technology exports are products with high } \mathrm{R} \& \mathrm{D} \text { intensity, } \\
\text { such as in aerospace, computers, pharmaceuticals, scientific } \\
\text { instruments, and electrical machinery. }\end{array}$ & $\uparrow$ \\
\hline 2014 & Real interest rate $(\%)$ & $\begin{array}{l}\text { Real interest rate is the lending interest rate adjusted for the } \\
\text { inflation measured by the GDP deflator. The terms and conditions } \\
\text { associated with loan rates differ from country to country, however, } \\
\text { limiting their comparability. }\end{array}$ & $\downarrow$ \\
\hline 2014 & $\begin{array}{l}\text { Total reserves (includes } \\
\text { gold, current US \$). }\end{array}$ & $\begin{array}{l}\text { Total reserves include monetary gold holdings, special drawing } \\
\text { rights, reserves of IMF members held by the IMF and holdings of } \\
\text { foreign exchange under the control of monetary authorities. The } \\
\text { gold component of these reserves is valued at year-end (December } \\
\text { 31) London prices. Data are in current US dollars. }\end{array}$ & $\uparrow$ \\
\hline
\end{tabular}

Table 4. Social Indicators

\begin{tabular}{|c|c|c|c|}
\hline \multicolumn{4}{|c|}{ Social Indicators } \\
\hline Year & Variable & Details & $\begin{array}{l}\text { Positive Ideal } \\
\text { Solution Scale }\end{array}$ \\
\hline 2014 & $\begin{array}{l}\text { Improved sanitation facilities ( } \% \\
\text { of population with access) }\end{array}$ & $\begin{array}{l}\text { Percentage of population using improved sanitation } \\
\text { facilities that are likely to ensure hygienic separation of } \\
\text { human excreta from human contact. }\end{array}$ & $\uparrow$ \\
\hline 2013 & $\begin{array}{l}\text { Public spending on education, } \\
\text { total }(\% \text { of GDP) }\end{array}$ & $\begin{array}{l}\text { General government expenditure on education (current, } \\
\text { capital and transfers) is expressed as a percentage of GDP. It } \\
\text { includes expenditure financed by transfers from } \\
\text { international sources to the government. }\end{array}$ & $\uparrow$ \\
\hline 2013 & $\begin{array}{l}\text { Level of education, higher } \\
\text { education (gross } \%)\end{array}$ & $\begin{array}{l}\text { Total is the total enrolment in higher education (ISCED } 5 \\
\text { and 6), regardless of age, expressed as a percentage of the } \\
\text { total population in the age group of five years following the } \\
\text { secondary school leaving. }\end{array}$ & $\uparrow$ \\
\hline 2013 & $\begin{array}{l}\text { Unemployment, Total } \\
\text { (\% of population) }\end{array}$ & $\begin{array}{l}\text { Unemployment refers to the share of the labour force that is } \\
\text { without work but available and seeking employment. }\end{array}$ & $\downarrow$ \\
\hline 2013 & $\begin{array}{l}\text { Health expenditure, total }(\% \text { of } \\
\text { GDP) }\end{array}$ & $\begin{array}{l}\text { Total expenditure on health is the sum of public and private } \\
\text { health expenditures. It covers the provision of health } \\
\text { services (preventive and curative), family planning } \\
\text { activities, nutrition activities and emergency aid designated } \\
\text { for health. }\end{array}$ & $\uparrow$ \\
\hline 2014 & HDI & Human development Index & $\uparrow$ \\
\hline
\end{tabular}


Table 5. Environmental indicators

\begin{tabular}{|c|c|c|c|}
\hline \multicolumn{4}{|c|}{ Environmental indicators } \\
\hline Year & Variable & Details & $\begin{array}{l}\text { Positive Ideal } \\
\text { Solution Scale }\end{array}$ \\
\hline 2013 & $\begin{array}{l}\text { Annual freshwater withdrawals, total } \\
\text { (billion cubic meters) }\end{array}$ & $\begin{array}{l}\text { Annual freshwater withdrawals refer to total water } \\
\text { withdrawals, not counting evaporation losses of storage } \\
\text { basins. Withdrawals also include water desalination plants } \\
\text { in countries where they are a significant source. } \\
\text { Withdrawals can exceed } 100 \text { percent of the total renewable } \\
\text { resources where the extraction from non-renewable } \\
\text { aquifers or desalination plants is considerable or where } \\
\text { there is significant water reuse. }\end{array}$ & $\downarrow$ \\
\hline 2013 & $\mathrm{CO}_{2}$ emissions (kt) & $\begin{array}{l}\text { Carbon dioxide emissions from fossil fuel burnings and } \\
\text { cement manufacturing. They include carbon dioxide } \\
\text { produced during consumption of solid, liquid and gas fuel } \\
\text { and gas burnings. }\end{array}$ & $\downarrow$ \\
\hline 2014 & Mammal species, endangered & $\begin{array}{l}\text { Mammal species are mammals excluding whales and } \\
\text { porpoises. Endangered species are the number of species } \\
\text { classified by the IUCN as endangered, vulnerable, rare, } \\
\text { indeterminate, out of danger, or insufficiently known. }\end{array}$ & $\downarrow$ \\
\hline 2013 & Plant species (higher), endangered & $\begin{array}{l}\text { Higher plants are native species of vascular plants. } \\
\text { Endangered species are the number of species classified by } \\
\text { the IUCN as endangered, vulnerable, rare, indeterminate, } \\
\text { out of danger, or insufficiently known. }\end{array}$ & $\downarrow$ \\
\hline 2013 & Forest area ( $\%$ of land area) & $\begin{array}{l}\text { Forest area is land under natural stands or planted of trees at } \\
\text { least } 5 \text { meters in situ, whether productive or not, and } \\
\text { excludes tree that stands in agricultural production systems } \\
\text { (for example in fruit plantations and agroforestry systems) } \\
\text { and trees in urban parks and gardens. }\end{array}$ & $\uparrow$ \\
\hline 2013 & $\begin{array}{l}\text { The consumption of fossil fuel energy } \\
\text { ( } \% \text { of total) }\end{array}$ & Fossil fuel comprises coal, oil and natural gas products. & $\downarrow$ \\
\hline 2013 & $\begin{array}{l}\text { Renewable fuels and waste ( } \% \text { of total } \\
\text { energy) }\end{array}$ & $\begin{array}{l}\text { Renewable fuels and waste comprise solid biomass, liquid } \\
\text { biomass, biogas, industrial waste and municipal waste, } \\
\text { measured as a percentage of total energy consumption. }\end{array}$ & $\uparrow$ \\
\hline
\end{tabular}

The choice of obtaining the selected indicators was based on available data of 2013 and 2014, and for the countries that did not have specific data for these periods, it was calculated as an average of previous years as of 2009 to characterize a reality closer to the present time. Thus, 175 countries were selected for the study. Some countries for which no data was available for some variables in economic, social and environmental indicators were displayed in the table index as zero and their indices were not considered in the application of the TOPSIS method.

In the TOPSIS method, the score for the criteria assumed that $m$ were the countries and $n$ the variables of the indicators, where the matrix was formed by $m \times n$. The variables $\mathrm{n}$ can assume positive and negative values. Initially, a standardized matrix was built from on data from the 175 countries surveyed, some variables of certain countries were not available in the database, so the next steps of the method was done according to the data available for each country. Firstly, for weighted standardized decision matrix the weights were considered with the same value (=1). It was necessary to determine the positive and negative ideal solution. In this case, the scale shown in tables 3, 4 and 5 was used and it was defined which variable should be calculated by "the higher value the better" or "the smaller value the better" to obtain the positive and negative ideal solutions. From there separation measures for each alternative were calculated. Standardized values of 19 variables were separated and calculated the positive and negative ideal alternative. Then the relative proximity was calculated to the ideal solution $\mathrm{Ci}^{*}$, sum of the ideal solutions and negative solutions already obtained. Thereby, it was possible to obtain the ranking of the countries taking into account each of its variables.

The use of AHP served for evaluation of the indicators and variables of sustainability, which are part of the model proposed. The structuring of the model for the AHP application was the following: 1 - Sustainability assessment of countries worldwide; 2 - Economic, Social and Environmental SIDs; 3 - Variables of each indicator (Figure 1). 


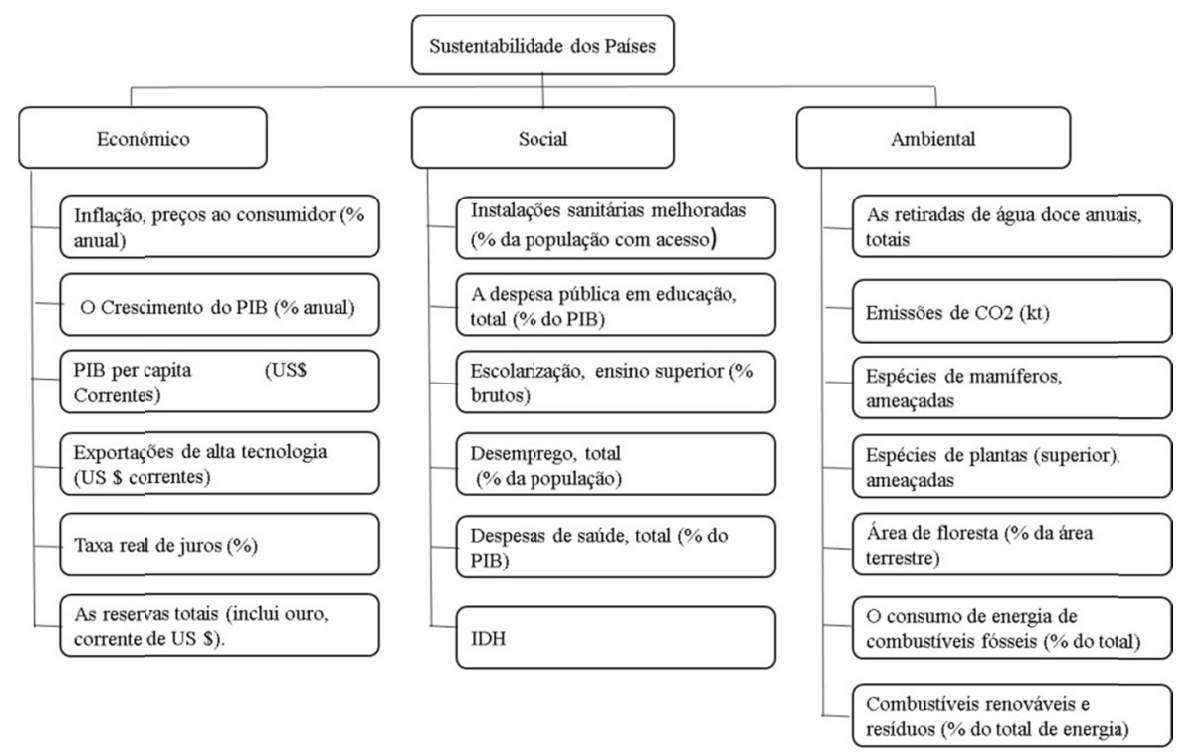

Figure 1. AHP Hierarchical Levels for Country sustainability

Evaluation of indicators and variables from the AHP method was done by pairs of these indicators and variables, comparing them to the selected criterion. An Excel spreadsheet was used to make these comparisons, while interviews were conducted with 14 experts: Two professors with a doctorate degree in Psychology and Plant Biology; and 12 students of Post-Graduation Course in Environmental Sciences. Responses from all interviewees were aggregated using the Aggregation of Individual Priorities (AIP) principle (Forman \& Peniwati, 1998).

\section{Results and Discussion}

\subsection{Application of TOPSIS Method}

The result of the application of the TOPSIS method provides an opportunity to compare the indicators and countries. Thus, the ranking of the countries from the largest to the smallest sustainability capacity is presented (Table 6).

Table 6. Rank of the top ten and last ten countries on economic, social, environmental and general (sum of previous three) indicators

\begin{tabular}{|c|c|c|c|c|c|c|c|c|}
\hline Rank & Countries & Economic & Countries & Social & Countries & Environmental & Countries & General \\
\hline 01 & China & 0.918 & Norway & 0.812 & Zambia & 0.969 & China & 0.786 \\
\hline 02 & Japan & 0.572 & United States & 0.772 & Mozambique & 0.956 & Japan & 0.602 \\
\hline 03 & United States & 0.541 & Switzerland & 0.743 & Congo & 0.947 & Germany & 0.575 \\
\hline 04 & Germany & 0.539 & Denmark & 0.668 & Zimbabwe & 0.944 & Korea & 0.567 \\
\hline 05 & Korea & 0.532 & Australia & 0.629 & Eritrea & 0.940 & Singapore & 0.565 \\
\hline 06 & Singapore & 0.529 & Netherlands & 0.602 & Cambodia & 0.939 & Switzerland & 0.564 \\
\hline 07 & Switzerland & 0.523 & Luxembourg & 0.594 & Nepal & 0.937 & France & 0.555 \\
\hline 08 & Saudi Arabia & 0.519 & Sweden & 0.589 & Angola & 0.937 & Saudi Arabia & 0.553 \\
\hline 09 & France & 0.518 & Austria & 0.587 & Swaziland & 0.935 & Netherlands & 0.544 \\
\hline 10 & Malaysia & 0.504 & Belgium & 0.554 & Haiti & 0.934 & United States & 0.542 \\
\hline 166 & Madagascar & 0.479 & Botswana & 0.170 & Pakistan & 0.798 & Pakistan & 0.514 \\
\hline 167 & Syria & 0.478 & Sudan & 0.168 & Madagascar & 0.793 & Indonesia & 0.513 \\
\hline 168 & Ukraine & 0.477 & Libya & 0.167 & Brazil & 0.787 & Belarus & 0.512 \\
\hline 168 & Mongolia & 0.476 & Namibia & 0.157 & Mexico & 0.781 & Madagascar & 0.511 \\
\hline 170 & Ghana & 0.473 & South Africa & 0.156 & Malaysia & 0.758 & Iran & 0.507 \\
\hline 171 & Iran & 0.468 & Macedonia & 0.155 & Indonesia & 0.723 & Ecuador & 0.499 \\
\hline 172 & Belarus & 0.466 & Gabon & 0.140 & Ecuador & 0.575 & Malawi & 0.495 \\
\hline 173 & Malawi & 0.443 & Bosnia & 0.126 & United States & 0.538 & India & 0.484 \\
\hline 174 & Sudan & 0.375 & Lesotho & 0.092 & China & 0.458 & Sudan & 0.449 \\
\hline 175 & Venezuela & 0.135 & Mauritania & 0.087 & India & 0.394 & Venezuela & 0.309 \\
\hline
\end{tabular}

In the economic indicator China was first, with an economic indicator 6.8 times higher than that of Venezuela 
which was the last. The difference between the economic indicator between China and the other countries is high. Compared with Japan, ranked second, China has almost double the value of the indicator. It was observed that the difference in the value of the economic indicators between the first ten and the last ten is not very large, with the exception of China and Venezuela. Unlike the economic indicator, the social indicator shows a large difference between the top ten and ten last countries. This is evident when we compare Belgium, which occupies the tenth position with Botswana occupying the hundred and sixty sixth. Thereby, the social indicator of Belgium was 3.25 times higher than Botswana. In the environmental indicator the first five positions were occupied by African countries, while India, China and the USA occupied the last, penultimate and antepenultimate position respectively.

These countries were behind Cambodia, Nepal, Angola, Haiti, Ecuador, among others. However, when comparing the general indicator, we observed that the countries with the highest economic indicators remained in the top ten. China and Japan were first and second, respectively, in the general rank, just as they had been in the economic rank, while Venezuela was last in the two ranks.

\subsection{Application of AHP Method}

The AHP method assigns weights to each indicator and the variables that compose them (Table 7).

Table 7. Rank of indicators and variables for intra-indicator and inter-indicator based on percentage of general weight to sustainability

\begin{tabular}{lllll}
\hline Indicators & Variables & intra-indicator & Inter-indicator & General weight \\
\hline Environmental & & & $\mathbf{1}$ & $\mathbf{4 7 . 0 3 \%}$ \\
& Freshwater withdrawal & 2 & 2 & $9.36 \%$ \\
& $\mathrm{CO}_{2}$ emissions & 3 & 3 & $7.91 \%$ \\
& Endangered mammal species & 7 & 16 & $2.38 \%$ \\
& Endangered Plant Species & 6 & 13 & $4.21 \%$ \\
& Forest area & 1 & 1 & $10.03 \%$ \\
& Consumption of fossil fuels & 5 & 8 & $5.89 \%$ \\
& Renewable fuels and waste & 4 & 5 & $7.24 \%$ \\
& & & $\mathbf{2}$ & $5.48 \%$ \\
& Improved sanitation facilities & 4 & 9 & $6.58 \%$ \\
& Public expenditure on education & 2 & 6 & $4.35 \%$ \\
& Higher education rate & 5 & 12 & $3.98 \%$ \\
& Total unemployment & 6 & 14 & $7.70 \%$ \\
& Total health expenditure & 1 & 4 & $6.06 \%$ \\
& HDI & 3 & 7 & $\mathbf{1 8 . 4 9 \%}$ \\
& & & $\mathbf{3}$ & $3.21 \%$ \\
& Inflation & 3 & 15 & $4.92 \%$ \\
& GDP growth (annual $\%)$ & 2 & 11 & $5.05 \%$ \\
& GDP per capita & 1 & 10 & $2.26 \%$ \\
& High-technology exports & 4 & 17 & $1.35 \%$ \\
& Real interest rate & 6 & 19 & $1.70 \%$ \\
\hline
\end{tabular}

Note. $*$ Numbers in bold are related to indicators.

The environmental indicator was the most important to sustainability with almost $50 \%$ of the total weight, while social and economic were second and third respectively. As a result, the variables of the environmental indicator were the most important, with emphasis on Forest area (10.03\%), Fresh water withdrawal $(9.36 \%)$ and $\mathrm{CO}_{2}$ emissions (7.91\%) which were the first three in the rank of intra and inter-indicator comparison. For the social indicator the intra-indicator Total health expenditure has large weight followed by Public expenditure on education and HDI while in inter-indicator ranking these variables occupied fourth, sixth and seventh positions. The economic indicator had the least weight in sustainability. Among its variables GDP per capita, GDP growth and Inflation were the most important within the economic indicator. However, because of the low weight of the indicator, these variables occupied the tenth, eleventh and fifteenth positions among all the variables.

\subsection{Application of TOPSIS-AHP Method}

With the TOPSIS-AHP method it was allowed to insert the weights of the indicators and their variables in the TOPSIS analysis, creating the weighted ranks for the countries. When we compared the two methods in relation to the rank of the countries for the general indicator, changes were observed (Table 8). 
Table 8. Comparative rank of TOPSIS and TOPSIS-AHP for top ten and last ten countries on general (sum of previous three) indicators

\begin{tabular}{lllll}
\hline Ranking & Countries & TOPSIS & Countries & TOPSIS-AHP \\
\hline 01 & China & 0.776 & Switzerland & 0.762 \\
02 & Japan & 0.602 & Norway & 0.751 \\
03 & Germany & 0.575 & Sweden & 0.741 \\
04 & Korea & 0.567 & Denmark & 0.728 \\
05 & Singapore & 0.565 & Germany & 0.726 \\
06 & Switzerland & 0.564 & Finland & 0.723 \\
07 & France & 0.555 & Austria & 0.722 \\
08 & Saudi Arabia & 0.553 & France & 0.714 \\
09 & Netherlands & 0.544 & Belgium & 0.709 \\
10 & United States & 0.542 & Luxembourg & 0.708 \\
166 & Pakistan & 0.514 & Iran & 0.608 \\
167 & Indonesia & 0.513 & Indonesia & 0.608 \\
168 & Belarus & 0.512 & Sudan & 0.606 \\
169 & Madagascar & 0.511 & Pakistan & 0.606 \\
170 & Iran & 0.507 & Libya & 0.594 \\
171 & Ecuador & 0.499 & Madagascar & 0.590 \\
172 & Malawi & 0.495 & Ecuador & 0.583 \\
173 & India & 0.484 & United States & 0.582 \\
174 & Sudan & 0.449 & Venezuela & 0.466 \\
175 & Venezuela & 0.309 & India & 0.412 \\
\hline
\end{tabular}

Comparing the two methods TOPSIS and TOPSIS-AHP countries rank to general indicator was observed many changes in ten first positions. China was first in TOPSIS rank but does not appear among the top ten in the TOPSIS-AHP rank. According to TOPSIS-AHP method, Switzerland, Norway and Sweden were the three most sustainable countries in the world. In addition, no country in the top ten has maintained the position in the sustainability ranks according to two indicators, with Korea Rep., Singapore, Netherlands, Saudi Arabia and the United States being replaced by Denmark, Sweden, Finland, Austria, Belgium and Luxembourg. In the ranking of the last positions, Venezuela occupied the last and penultimate positions regarding sustainability, under the two methods TOPSIS and TOPSIS-AHP respectively. However, the most significant change between the two methods was the position of the United States. This country ranked tenth in TOPSIS and then became the third worst country in sustainability in TOPSIS-AHP. It was also observed that there was a greater difference between the values of the general indicator in TOPSIS in relation to TOPSIS-AHP.

In this article SDI was considered as the sum of the economic, social and environmental indicators. Given this, the TOPSIS method proved to be weak in relation to ranking countries in terms of sustainability. In this method, countries like China and the United States, countries with a history of polluters and, in the case of China, low social concern were in the top positions on sustainability. This was because these countries had high economic indicators that when added to the social and environmental indicators raise the values of sustainability for these countries. China, Japan, the United States, where the largest sources of employment, technology and production of consumer goods are concentrated worldwide, where in fact the variables High Technology Exports had general weight of $2.26 \%$ and total reserves had general weight of $1.70 \%$ were among the top 8 . In this way, the use of TOPSIS to rank countries on sustainability is compromised, since SDI values will always be those of the highest value indicator in the sum. When using the TOPSIS-AHP method, the top ten positions were from European countries. Switzerland, Norway, Sweden, Denmark and Germany are the most sustainable globally. These countries have a long history of sustainable practices in many sectors, as well as being pioneers in these measures. In this way, it is evident that TOPSIS-AHP produced a more realistic rank as compared to the other method. Unlike TOPSIS, TOPSIS-AHP ranked the United States with low sustainability score. Although it has several mechanisms to promote sustainability, it finds many restrictions on the sustainable model in the most different economic sectors. This was due to the low environmental indicators that the country has. This low environmental performance is related, among other factors, to the refusal of the United States to reduce the emission of pollutants and the high consumption of American society. However, the TOPSIS-AHP method, as it was more robust, made a more realistic assessment of countries are closer to sustainability. This became evident when we look at the United States case again. With the sustainability value obtained by the country in the TOPSIS-AHP method (0.582), it is occupying the hundred seventy-second position in the TOPSIS-AHP, whereas it was in the third position according to TOPSIS method. This method then promoted greater homogeneity 
among the countries that occupy the top of the rank and greater difference between the first ten and the last ten.

In comparison with the rank of the general indicator, the rank of the economic indicator had few changes when compared the methods used (Table 9).

Table 9. Comparative rank of TOPSIS and TOPSIS-AHP for top ten and last ten countries on economic indicators

\begin{tabular}{|c|c|c|c|c|}
\hline Ranking & Countries & TOPSIS & Countries & TOPSIS-AHP \\
\hline 01 & China & 0.918 & China & 0.924 \\
\hline 02 & Japan & 0.572 & Japan & 0.655 \\
\hline 03 & United States & 0.541 & United States & 0.654 \\
\hline 04 & Germany & 0.539 & Germany & 0.652 \\
\hline 05 & Korea & 0.532 & Singapore & 0.645 \\
\hline 06 & Singapore & 0.529 & Switzerland & 0.640 \\
\hline 07 & Switzerland & 0.523 & Korea & 0.630 \\
\hline 08 & Saudi Arabia & 0.519 & Norway & 0.618 \\
\hline 09 & France & 0.518 & Luxembourg & 0.616 \\
\hline 10 & Malaysia & 0.504 & France & 0.616 \\
\hline 166 & Madagascar & 0.479 & Syrian & 0.528 \\
\hline 167 & Syrian & 0.478 & Gambia & 0.524 \\
\hline 168 & Ukraine & 0.477 & Iran & 0.521 \\
\hline 169 & Mongolia & 0.476 & Belarus & 0.520 \\
\hline 170 & Ghana & 0.473 & Ukraine & 0.511 \\
\hline 171 & Iran & 0.468 & Malawi & 0.488 \\
\hline 172 & Belarus & 0.466 & Madagascar & 0.467 \\
\hline 173 & Malawi & 0.443 & Libya & 0.455 \\
\hline 174 & Sudan & 0.375 & Sudan & 0.415 \\
\hline 175 & Venezuela & 0.135 & Venezuela & 0.138 \\
\hline
\end{tabular}

For the economic indicator, the best performances in the TOPSIS and TOPSIS-AHP applications belong to China, Japan, the United States, Germany, Republic of Korea, Singapore, Switzerland and France, which as expected have remained among the top ten, mainly. Norway and Luxembourg are nowhere in the top 10 according to TOPSIS, but in TOPSIS-AHP, they occupy 8th and 9th places. On the other hand, Saudi Arabia and Malaysia are in 12th and 19th places in TOPSIS-AHP. In the top ten countries the top four positions are held by the same countries, while Saudi Arabia and Malaysia gave way to Norway and Luxembourg. The countries with the worst economic performance in both TOPSIS and TOPSIS-AHP were Venezuela, Sudan, Malawi, Belarus, Iran, Ukraine, Syrian Arab Republic and Madagascar. As in the general indicator, the values of the economic indicator were larger, on an average by 0.1 , in the TOPSIS-AHP method in relation to the TOPSIS. With the exception of China and Venezuela, the difference between the indicators of countries from the top to the countries at the bottom of the rank was not so marked.

In economic indicators, the TOPSIS-AHP method does not differ from TOPSIS in the first and last positions. Thus, China, Japan, United States and Germany remained in the same positions on both lists. This is due to the low weight assigned to the economic variables in the TOPSIS-AHP. So we can consider they have the economic indicator leveled with the other indicators, since this had very low weights for their variables $(18.49 \%)$. When taking into account results of the survey done with the experts, economic indicator exerts little influence on the other indicators for these countries, since their weight was the lowest in the survey. In this method the entry of Norway and Luxembourg and the departure of Saudi Arabia and Malaysia were due to the greater environmental weight that this method places on environmental variables. Saudi Arabia has a strong economy due to oil reserves, while Malaysia is one of the emerging countries that has been emerging in several economic sectors because of local and international investments. The countries with the lowest economic indicators generally do not have an economic stability or investments in the production and consumption of goods to meet their demands. Venezuela, for example, is a country that is experiencing an economic turbulence due to the political conditions the country is facing.

In the rank of the social indicator the countries of the upper part presented a great difference in relation to those of the lower part (Table 10). 
Table 10. Comparative rank of TOPSIS and TOPSIS-AHP for top ten and last ten countries on social indicators

\begin{tabular}{|c|c|c|c|c|}
\hline Ranking & Countries & TOPSIS & Countries & TOPSIS-AHP \\
\hline 01 & Norway & 0.812 & Norway & 0.855 \\
\hline 02 & United States & 0.772 & United States & 0.798 \\
\hline 03 & Switzerland & 0.743 & Switzerland & 0.776 \\
\hline 04 & Denmark & 0.668 & Denmark & 0.692 \\
\hline 05 & Australia & 0.629 & Australia & 0.644 \\
\hline 06 & Netherlands & 0.602 & Sweden & 0.608 \\
\hline 07 & Luxembourg & 0.594 & Austria & 0.607 \\
\hline 08 & Sweden & 0.589 & Luxembourg & 0.604 \\
\hline 09 & Austria & 0.587 & Netherlands & 0.582 \\
\hline 10 & Belgium & 0.554 & Belgium & 0.579 \\
\hline 166 & Botswana & 0.170 & Zambia & 0.122 \\
\hline 167 & Sudan & 0.168 & Uganda & 0.116 \\
\hline 168 & Libya & 0.167 & Sudan & 0.116 \\
\hline 169 & Namibia & 0.157 & Sierra Leone & 0.116 \\
\hline 170 & South Africa & 0.156 & Guinea Bissau & 0.115 \\
\hline 171 & Mecedonia & 0.155 & Eritrea & 0.110 \\
\hline 172 & Gabon & 0.140 & Madagascar & 0.109 \\
\hline 173 & $\begin{array}{l}\text { Bosnia } \\
\text { Hezergovina }\end{array}$ & and 0.126 & Chad & 0.090 \\
\hline 174 & Lesotho & 0.09 & Mauritania & 0.086 \\
\hline 175 & Mauritania & 0.08 & Lesotho & 0.084 \\
\hline
\end{tabular}

The upper countries had an average value of 0.674 for the social indicator, while last countries had a value of 0.106 which represents a value 6 times higher for the top countries. Among the countries with the highest social indicator, Norway, United States, Switzerland, Denmark, Australia, Netherlands, Luxembourg, Sweden, Austria and Belgium achieved the best performances among the 175 countries in TOPSIS and TOPSIS-AHP, there the top five positions remained unchanged, while the Netherlands lost three positions and Luxembourg one; Sweden and Austria win two. There was no entry or exit in the group of ten countries with the highest social indicator. On the contrary, in the countries with the lowest social indicator, the change in TOPSIS has led to the exit of seven countries from the last positions, besides promoting the inversion of Mauritania and Lesotho in the last and penultimate positions. These two countries and Sudan remain in the last positions in both methods.

In the social indicators European continent was featured with eight countries among the top ten. In fact, social policies and greater state participation in various sectors of European society contribute to more social investments in relation to other economic ones. The few differences observed between the methods are due to the lower weight of this indicator for TOPSIS-AHP. However, for the countries at the bottom of the ranking, the weighting of the social variables changed the order of the countries. Unlike TOPSIS, in the TOPSIS-AHP method, it took occupation of the last ten positions only by African countries. In fact, most countries in the African continent have a lower standard of living, with economic crises, high infant mortality rates and consequently lower welfare level and social sustainability, especially in the variables evaluated. The use of the different methods also significantly modified the rank of countries as per the environmental indicator, especially among the ten best placed countries (Table 11). 
Table 11. Comparative rank of TOPSIS and TOPSIS-AHP for top ten and last ten countries on environmental indicators

\begin{tabular}{lllll}
\hline Ranking & Countries & TOPSIS & Countries & TOPSIS-AHP \\
\hline 01 & Zambia & 0.969 & Zambia & 0.967 \\
02 & Mozambique & 0.956 & Congo, Dem. Rep. & 0.966 \\
03 & Congo & 0.947 & Mozambique & 0.954 \\
04 & Zimbabwe & 0.944 & Cambodia & 0.943 \\
05 & Eritrea & 0.940 & Ethiopia & 0.940 \\
06 & Cambodia & 0.93 & Gabon & 0.939 \\
07 & Nepal & 0.937 & Eritrea & 0.938 \\
08 & Angola & 0.937 & Nepal & 0.938 \\
09 & Swaziland & 0.935 & Zimbabwe & 0.935 \\
10 & Haiti & 0.934 & Congo & 0.934 \\
166 & Pakistan & 0.798 & Malaysia & 0.784 \\
167 & Madagascar & 0.793 & Trinidad and Tobago & 0.773 \\
168 & Brazil & 0.787 & Iran & 0.772 \\
169 & Mexico & 0.781 & Pakistan & 0.757 \\
170 & Malaysia & 0.758 & Indonesia & 0.757 \\
171 & Indonesia & 0.723 & Mexico & 0.746 \\
172 & Ecuador & 0.575 & Ecuador & 0.689 \\
173 & United States & 0.538 & United States & 0.464 \\
174 & China & 0.458 & China & 0.409 \\
175 & India & 0.394 & India & 0.306 \\
\hline
\end{tabular}

Of the countries that occupied the top ten positions in the two methods, all but Nepal came from the African continent, highlighting the variables Consumption of Energy from Fossil Fuels (7.42\%) and Renewable Fuels and Waste (5.89\%). Among these countries, Zambia was the country with the highest environmental indicator in both methods, while Zimbabwe lost five positions, Eritrea two, Nepal one and Cambodia won two, when TOPSIS-AHP was applied.

The application of the method caused the departure of Angola, Swaziland and Haiti promoting the entry of Ethiopia, Gabor and Congo in the countries with the highest environmental indicator. Among the countries with the worst environmental indicator, the last five positions remained unchanged in the different methods, with India, China and the United States occupying last, penultimate and antepenultimate positions in rank. However, the use of TOPSIS-AHP led to the loss of four positions for Malaysia, three for Pakistan and one for Mexico. In addition, the method has caused the exit of Brazil and Madagascar, promoting the entry of Iran and Trinidad and Tobago into the last ten positions of environmental indicators. TOPSIS-AHP method also worsened the distance between the last three (India, China and the United States) and the fourth worst, Ecuador, where the mean difference increased from 0.075 to 0.296 .

Luzzati \& Gucciardi, 2015 carried out a sustainability ranking of the European Union (EU) countries, selecting 76 indicators for the $27 \mathrm{EU}$ countries but adopting a different methodology obtained the following final rankings: Ireland, Sweden, the Netherlands, Austria, Finland, United Kingdom, Belgium, Germany, France and Italy, which were very similar to those obtained in this paper. Another survey used 75 indicators for 128 countries, however it was taking into account data prior to 2011, and the proposed ranking has the following countries: Switzerland, Sweden, Finland, Denmark, Norway, Austria, France, the Netherlands, Germany and Belgium (Phillis, Grigoroudis, \& Kouikoglou, 2011). The only difference to the result presented in this study with the TOPSIS-AHP is the inclusion of Luxembourg rather than the Netherlands. This shows that there has not been much change in the ranking of countries regarding sustainability in recent years, and that this result is due to the fact that these countries have a balance in the economic, social and environmental segments. In addition, it is possible to perceive that the concern with sustainability is even greater in the countries classified as "developed". Thus, the results of this study corroborate prior research. It is important to point out that the application of TOPSIS-AHP becomes a consistent method for ranking countries in the perspective of sustainability.

Within the variables selected, the ranking of the countries regarding the economic, social and environmental indicators of sustainability had high and low results, but in the final result, even giving greater weight to one variable than another, there were no discrepant oscillations in the use of the TOPSIS method with and without the influence of the experts. With the exception of the final result, where there was the sum of the three indicators, economic, social and environmental, in which Saudi Arabia (134th), China (165th) and the United States (173th) went from the first weightless positions to the end of the table with the weightages assigned by the 
experts, the other results were stable and without much oscillation. This result can also be considered as a starting point for the global analysis, since it reveals strengths and weaknesses of each country. The greatest difficulty in assessing sustainability is the challenge of exploring and analyzing a holistic system (Hardi \& Zdan, 2000). For this author, a holistic view does not only require a vision of the complex economic, social and ecological systems, but also the interaction between these systems.

\section{Conclusion}

Comparing the two methods, it was evident that TOPSIS-AHP was more judicious due to the weights attributed to the qualitative variables by the specialists. However, because all the experts were from environmental areas, there was a bias towards higher importance of environmental variables in sustainability. Accordingly, AHP test showed that the environmental indicator is the most important for assessing sustainability at the expense of economic and social indicators. However, for a less biased analysis it would be necessary the opinion of experts from the three areas evaluated. In this way, there could be more debate about the weights of the economic and social areas for composition of matrix with weights. The largest discrepancy observed among SDI methods in relation to the other indicators was related to the fact that SDI is the sum of economic, social and environmental indicators. When there is strong correlation between the economic, social and environmental indicators, only one indicator cannot be held responsible for the global degradation. In fact, the three indicators together play a key role in improving the sustainability of countries and need to develop together. However, TOPSIS-AHP was a consistent method for ranking countries in the perspective of sustainability. This is a starting point for the overall analysis as it reveals the strengths and weaknesses of each country. Indeed, these results are a stimulus for developing countries to increasingly improve the issue of sustainable development and for other countries to seek the causes of their sustainability weaknesses in order to correct them. In addition, results of this study warn the governance of countries so that they can carry out effective measures in pursuit of a truly sustainable development, not focusing on only one of the indicators described in this work. In addition, we can consider that one implication for those responsible for guiding the countries' growth is the effective perception of the impact generated by the neglect of sustainability. Moreover, the purpose of using economic, social and environmental indicators in this study, although much discussed in recent years, is to present more current information on global sustainability, since we suffer daily with the impact generated, and it is possible to identify them in our daily lives. We can see the need for these economic, social and environmental pillars to be studied more and more in an integrated way, and no longer separated into categories, so that a sustainable assessment can be obtained and the deficient pillar corrected for balance. With that, we hope to contribute to the growth of actions and innovations where sustainable development is a priority, making it stronger for a truly sustainable planet. Accordingly, with the result and knowledge obtained in the development of this study, the following future works are suggested:

- Identify the possibility of introducing new indicators and new variables that have not been evaluated in these studies;

- Conduct a comparative study from time to time to present the countries that are really seeking sustainability;

- One suggestion to continue this research is to carry out new studies using other methods of decision making;

- We suggest applying AHP to other expert groups from different areas so that the main variables can be searched and identified from different points of view.

- Specifically for Brazil, the same study could be carried out considering the States and Municipalities, so that politicians can be attentive to sustainability in the economic, social and environmental trinomial.

\section{References}

Aragonés-Beltrán, P., Chaparro-González, F., Pastor-Ferrando, J. P., \& Pla-Rubio, A. (2014). An AHP (Analytic Hierarchy Process)/ANP (Analytic Network Process)-based multi-criteria decision approach for the selection of solar-thermal power plant investment projects. Energy, 66, 222-238. https://doi.org/10.1016/j.energy.2013.12.016

Behzadian, M., Otaghsara, S. K., Yazdani, M., \& Ignatius, J. (2012). A state-of the-art survey of TOPSIS $\begin{array}{lllll}\text { applications. } \quad \text { Expert } & \text { Systems with Applications, } & 39, & 13051-13069 .\end{array}$ https://doi.org/10.1016/j.eswa.2012.05.056

Bohringer, C., \& Jochem, P. E. (2007). Measuring the immeasurable-A survey of sustainability indices. Ecological Economics, 63, 1-8. https://doi.org/10.1016/j.ecolecon.2007.03.008 
Brundtland, G. H. (1985). World commission on environment and development. Environmental Policy and Law, 14, 26-30. https://doi.org/10.1016/S0378-777X(85)80040-8

Bulgurcu, B. K. (2012). Application of TOPSIS technique for financial performance evaluation of technology firms in Istanbul stock exchange market. Procedia-Social and Behavioral Sciences, 62, 1033-1040. https://doi.org/10.1016/j.sbspro.2012.09.176

Ciegis, R., Ramanauskiene, J., \& Startiene, G. (2015). Theoretical reasoning of the use of indicators and indices for sustainable development assessment. Engineering Economics, 63.

Distaso, A. (2007). Well-being and/or quality of life in EU countries through a multidimensional index of sustainability. Ecological Economics, 64, 163-180. https://doi.org/10.1016/j.ecolecon.2007.02.025

Egilmez, G., Gumus, S., \& Kucukvar, M. (2015). Environmental sustainability benchmarking of the US and Canada metropoles: An expert judgment-based multi-criteria decision making approach. Cities, 42, 31-41. https://doi.org/10.1016/j.cities.2014.08.006

Ertugrul, Í., \& Karakaçoglu, N. (2009). Performance evaluation of Turkish cement firms with fuzzy analytic hierarchy process and TOPSIS methods. Expert Systems with Applications, 36. https://doi.org/10.1016/j.eswa.2007.10.014

Forman, E., \& Peniwati, K. (1998). Aggregating individual judgments and priorities with the analytic hierarchy process. European Journal of Operational Research, 108(1), 165-169. https://doi.org/10.1016/S0377-2217(97)00244-0

Hardi, P., \& Zdan, T. J. (2000). The Dashboard of Sustainability. Draft paper. Winnipeg: IISD.

Hossaini, N., Reza, B., Akhtar, S., Sadiq, R., \& Hewage, K. (2015). AHP based life cycle sustainability assessment (LCSA) framework: a case study of six storey wood frame and concrete frame buildings in Vancouver. Journal of Environmental Planning and Management, 58, 1217-1241. http://dx.doi.org/10.1080/09640568.2014.920704

Jingzhu, Z., \& Opschoor, J. B. (1999). Indicator system and evaluation framework for sustainable development. Environmental Sciences, 11, 492-497.

Luzzati, T., \& Gucciardi, G. (2015). A non-simplistic approach to composite indicators and rankings: an illustration by comparing the sustainability of the EU countries. Ecological Economics, 113, 25-38. https://doi.org/10.1016/j.ecolecon.2015.02.018

Phillis, Y. A., Grigoroudis, E., \& Kouikoglou, V. S. (2011). Sustainability ranking and improvement of countries. Ecological Economics, 70, 542-553. https://doi.org/10.1016/j.ecolecon.2010.09.037

Rametsteiner, E., Pülzl, H., Alkan-Olsson, J., \& Frederiksen, P. (2011). Sustainability indicator development-Science or political negotiation? Ecological Indicators, 11, 61-70. https://doi.org/10.1016/j.ecolind.2009.06.009

Ramos, T. B., \& Caeiro, S. (2010). Meta-performance evaluation of sustainability indicators. Ecological Indicators, 10, 157-166. https://doi.org/10.1016/j.ecolind.2009.04.008

Saaty, T. L. (2008). Decision making with the analytic hierarchy process. International Journal of Services Sciences, 1, 83-98. https://doi.org/10.1504/IJSSci.2008.01759

Shields, D. J., Solar, S. V., \& Martin, W. E. (2002). The role of values and objectives in communicating

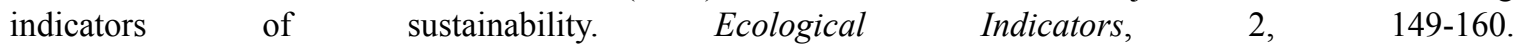
https://doi.org/10.1016/S1470-160X(02)00042-0

Spangenberg, J. H., Pfahl, S., \& Deller, K. (2002). Towards indicators for institutional sustainability: lessons from an analysis of Agenda 21. Ecological Indicators, 2, 61-77. https://doi.org/10.1016/S1470-160X(02)00050-X

Zhu, B. \& Xu, Z. (2014). Analytic hierarchy process-hesitant group decision making. European Journal of Operational Research, 239, 794-801. https://doi.org/10.1016/j.ejor.2014.06.019

Waas, T., Hugé, J., Block, T., Wright, T., Benitez-Capistros, F., \& Verbruggen, A. (2014). Sustainability assessment and indicators: Tools in a decision-making strategy for sustainable development. Sustainability, 6, 5512-5534. https://doi.org/10.3390/su6095512

White, L., \& Noble, B. F. (2013). Strategic environmental assessment for sustainability: A review of a decade of academic research. Environmental Impact Assessment Review, 42, 60-66. 
https://doi.org/10.1016/j.eiar.2012.10.003

Wiedmann, T. O., Schandl, H., Lenzen, M., Moran, D., Suh, S., West, J., \& Kanemoto, K. (2015). The material footprint of nations. PNAS, 112, 6271-6276. https://doi.org/10.1073/pnas.1220362110

\section{Copyrights}

Copyright for this article is retained by the author(s), with first publication rights granted to the journal.

This is an open-access article distributed under the terms and conditions of the Creative Commons Attribution license (http://creativecommons.org/licenses/by/4.0/). 